\title{
Organizational Condition of Private Schools and Colleges in Nueva Ecija
}

\author{
Kim Edward S. Santos ${ }^{1,2}$, Carl Louie R. Nocum ${ }^{1,2}$ \\ ${ }^{1}$ Wesleyan University-Philippines, Cabanatuan, Philippines \\ ${ }^{2}$ College of Management and Business Technology, Atate Campus, Nueva Ecija University of Science and Technology, \\ Cabanatuan, Philippines \\ Email:kimnyte@gmail.com, kesantos@neust.edu.ph,carlnocum1995@gmail.com
}

How to cite this paper: Santos, K.E.S. and Nocum, C.L.R. (2020) Organizational Condition of Private Schools and Colleges in Nueva Ecija. Open Access Library Journal, 7: e6112.

https://doi.org/10.4236/oalib.1106112

Received: January 28, 2020

Accepted: February 14, 2020

Published: February 17, 2020

Copyright $\odot 2020$ by author(s) and Open Access Library Inc.

This work is licensed under the Creative Commons Attribution International License (CC BY 4.0).

http://creativecommons.org/licenses/by/4.0/

(c) (i) Open Access

\begin{abstract}
Healthy organizations need to maximize human resources to achieve their goals; they need to integrate their programs and empower their employees. The study described the organizational condition of private schools and colleges in Nueva Ecija in terms of organizational structure, employer-employee relationship, and employee's growth and development. The study used descriptive method and utilized survey research. A total of 114 employees (composed of 76 teaching and 38 non-teaching staff) from private schools and colleges in Nueva Ecija were involved in this study. Based on the gathered data and analysis of the results, the researchers concluded that the private schools and colleges of Nueva Ecija have demonstrated to be very satisfactory in their organizational condition. This was highlighted in the aspects of organizational structure and employee's growth and development. This focuses on the commitment of all the members in achieving goals and objectives of their organizations, and at the same time giving opportunities to all the members to become productive according to distributed roles, and responsibilities, acknowledging one's accomplishments, and group cohesiveness.
\end{abstract}

\section{Subject Areas}

Business and Economics Education, Education, Organizational Behavior, Organizational Behavior and Theory

\section{Keywords}

Organization, Organizational Structure, Organization Health, Employer-Employee Relationship, Employee-Employee Relationship, Growth and Development 


\section{Introduction}

Healthy organizations need to maximize human resources to achieve their goals; they need to integrate their programs and empower their employees. Instead of conventional organizational structures that rely heavily on resource control and cost reduction, productivity, and profitability economic principles, the emphasis of modern companies is on human capital management [1].

In order to evaluate effectively the organizational conditions for healthy work, other aspects of the work system must be considered simultaneously [2]. Organizational wellbeing can be characterized as how well an organization is able to cope with the pressures of different principles for the good of the people, the staff and the organization in general [3].

Having established the fact that teachers are important for the schools' good organizational condition, school administrators are encouraged to inspire and enable teachers to turn this into the success that will inevitably lead to better students' academic performance [4].

In line with the foregoing insights, it is timely and relevant that the researchers assess the organizational conditions of private schools and colleges in Nueva Ecija.

\section{Conceptual Framework}

Healthy workplaces acknowledge the requirement to appear past the lowest line to the foremost important business component, the people [5]. Organization health promises employees' commitment to organization management and employee performance increase by creating a desired work environment [6].

Schools' organizational health as a key component has tremendous impact on students' academic achievement as the final quality of the education system [7]. The aspects in primary school organization structures are involved relationships such as Principal Support (principal-teacher relationship) and Teacher Collegiality (teacher-teacher relationships) [8].

\section{Objective of the Study}

The study described the organizational condition of private schools and colleges in Nueva Ecija in terms of organizational structure, employer-employee relationship, and employee's growth and development.

\section{Methodology}

The study used descriptive method as it is a basic research approach which looks at the situation as it exists in its present state [9]. A total of 114 employees from private schools and colleges in Nueva Ecija were involved in this study. They were composed of 76 teaching staff and 38 non-teaching staff. The study utilized survey research as it incorporates scientific methods through critical analysis and evaluation of source materials, data analysis and interpretation, and generalization and prediction [10]. 


\section{Results and Discussion}

Table 1 shows the organizational structure as an aspect of the organizational condition of private schools and colleges in Nueva Ecija. Based on the results, the organizational structure aspect got a mean of 3.96 with a verbal interpretation of "agreed to great extent". This describes that the private schools and colleges in Nueva Ecija show that their organizations distribute positions, powers, and responsibilities to its members accordingly $(X=4.50)$; there are clear policies and goals of the organization that supports the need of both the organization and its employees $(X=4.26)$; and necessary information from the organization is readily available to every employee $(X=4.20)$. All these items have verbal interpretations of "completely agree" that imply the organizational condition of the private school and colleges has offered equality among its members especially in terms of distribution of power, positions, and responsibilities. Furthermore, the organization also focuses on their goals and policies and the communication exists adequately within the organization.

Table 2 shows the employer-employee relationship as an aspect of organizational condition. Based on the results, the private schools and colleges in Nueva Ecija got a weighted mean of 3.26 with a verbal interpretation of "agreed to some extent". This describes that private schools and colleges as organizations put appropriate measures to resolve misunderstanding and conflicts within the organization ( $\mathrm{X}=3.98)$; cooperation between the employers and employees is observed towards the operation of the organization $(X=48)$; and the management puts appropriate measures to resolve misunderstand and conflicts within the

Table 1. Organizational condition of private schools and colleges in Nueva Ecija in terms of their organizational structure.

\begin{tabular}{|c|c|c|}
\hline Statements & Mean & Verbal Description \\
\hline $\begin{array}{l}\text { 1. The organization and the employees know their } \\
\text { common goal to work with. }\end{array}$ & 3.45 & Agreed to Great Extent \\
\hline $\begin{array}{l}\text { 2. There are clear policies and goals of the organization } \\
\text { that supports the need of both the organization and its } \\
\text { employees. }\end{array}$ & 4.26 & Completely Agreed \\
\hline $\begin{array}{l}\text { 3. Each employee is working in the organization towards } \\
\text { achieving the goals of the organization. }\end{array}$ & 4.11 & Agreed to Great Extent \\
\hline $\begin{array}{l}\text { 4. Necessary information from the organization is readily } \\
\text { available to every employee. }\end{array}$ & 4.24 & Completely Agreed \\
\hline $\begin{array}{l}\text { 5. Channeling of communication is arranged accordingly } \\
\text { from the senior administrators down to the staff. }\end{array}$ & 3.54 & Agreed to Great Extent \\
\hline $\begin{array}{l}\text { 6. The organizational structure functions well based on its } \\
\text { stated policies and goals. }\end{array}$ & 4.20 & Agreed to Great Extent \\
\hline $\begin{array}{l}\text { 7. The organization distributes positions, powers, and } \\
\text { responsibilities to its members accordingly. }\end{array}$ & 4.50 & Completely Agreed \\
\hline $\begin{array}{l}\text { 8. Decisions in the organizations are taken by the head of } \\
\text { the organization and the employees together. }\end{array}$ & 3.40 & Agreed to Some Extent \\
\hline Weighted Mean & 3.96 & Agreed to Great Extent \\
\hline
\end{tabular}


Table 2. Organizational condition of private schools and colleges in Nueva Ecija in terms of their employer-employee relationship.

\begin{tabular}{|c|c|c|}
\hline Statements & Mean & Verbal Description \\
\hline $\begin{array}{l}\text { 1. There is a strong sense of belongingness among the } \\
\text { members of the organization. }\end{array}$ & 2.84 & Agreed to Some Extent \\
\hline $\begin{array}{l}\text { 2. Employees are provided with the encouragement to work } \\
\qquad \text { well. }\end{array}$ & 2.92 & Agreed to Some Extent \\
\hline $\begin{array}{l}\text { 3. The employees of the organization feel free in expressing } \\
\text { their opinions about the concerning the organization. }\end{array}$ & 2.63 & Agreed to Some Extent \\
\hline $\begin{array}{l}\text { 4. Cooperation between the employers and employees is } \\
\text { observed towards the operation of the organization }\end{array}$ & 3.48 & Agreed to Great Extent \\
\hline $\begin{array}{l}\text { 5. The employers recognize the strengths and weaknesses of } \\
\text { their employees. }\end{array}$ & 3.43 & Agree to Great Extent \\
\hline $\begin{array}{l}\text { 6. The members of the organization can see without } \\
\text { hesitation their higher authorities and senior colleagues. }\end{array}$ & 3.40 & Agree to Some Extent \\
\hline $\begin{array}{l}\text { 7. The management puts appropriate measures to resolve } \\
\text { misunderstand and conflicts within the organization. }\end{array}$ & 3.98 & Agree to Great Extent \\
\hline $\begin{array}{l}\text { 8. The organization is attentive to the needs of its } \\
\text { members. }\end{array}$ & 3.40 & Agree to Some Extent \\
\hline Weighted Mean & 3.26 & Agreed to Some Extent \\
\hline
\end{tabular}

organization $(\mathrm{X}=3.43)$. The result implies that private schools and colleges show cohesiveness of the organizations' members and develop the feeling of belongingness that can create good indicator to have appropriate actions in dealing with one another.

Table 3 shows that the weighted mean of the employee's growth and development as an aspect of the organizational condition of private schools and colleges in Nueva Ecija got a weighted mean of 3.50 with a verbal interpretation of "agreed to great extent". This describes that employees of these organizations have the effort in smoothly adapting the changing environment ( $X=12$; "agreed to great extent'); and the employees offer the credit of their personally accomplished achievements to the organization ( $X=4.01$; "agreed to great extent"). However, with a mean of 2.68 ("agreed to some extent"), as an organization, the employees were given ample opportunities to be the kind of persons they want to be. The results imply that private schools and colleges in Nueva Ecija take into considerations the growth and development of their employees by acknowledging personal accomplishments and supporting the effort of the employees in adapting to change as part of growth.

Table 4 shows the Evaluation Summary of organizational condition of private schools and colleges in Nueva Ecija.

Results show that the aspects like organizational structure $(X=3.96)$ and employee's growth and development $(X=3.50)$ both with verbal interpretation of "agreed to great extent" and evaluated as "very satisfactory" while the employer-employee relationship aspect $(X=3.26)$ with a verbal description of "agreed 
Table 3. Organizational condition of private schools and colleges in Nueva Ecija in terms of employee's growth and development.

\begin{tabular}{|c|c|c|}
\hline Statements & Mean & Verbal Description \\
\hline $\begin{array}{l}\text { 1. There are ample opportunities for the employees to be } \\
\text { the kind of persons they want to be. }\end{array}$ & 2.68 & Agreed to Some Extent \\
\hline $\begin{array}{l}\text { 2. The employees offer the credit of their personally } \\
\text { accomplished achievements to the organization. }\end{array}$ & 4.01 & Agreed to Great Extent \\
\hline $\begin{array}{l}\text { 3. Every employee tries his work useful, creative and } \\
\text { meaningful. }\end{array}$ & 3.37 & Agreed to Some Extent \\
\hline $\begin{array}{l}\text { 4. Employees have their freedom to fulfil their roles and } \\
\text { responsibilities. }\end{array}$ & 3.43 & Agreed to Great Extent \\
\hline 5. Every employee of this organization works punctually. & 3.58 & Agreed to Great Extent \\
\hline $\begin{array}{l}\text { 6. The effort of the employees is smoothly adapting the } \\
\text { changing environment of the organization. }\end{array}$ & 4.12 & Agreed to Great Extent \\
\hline $\begin{array}{l}\text { 7. The members of this organization never feel conflict } \\
\text { between what they are and what they should be. }\end{array}$ & 3.40 & Agreed to Some Extent \\
\hline $\begin{array}{l}\text { 8. All the employees are active for the progress of the } \\
\text { organization. }\end{array}$ & 3.40 & Agreed to Some Extent \\
\hline Weighted Mean & 3.50 & Agreed to Great Extent \\
\hline
\end{tabular}

Table 4. Evaluation summary of organizational condition of private schools and colleges in Nueva Ecija.

\begin{tabular}{|c|c|c|c|}
\hline Aspects & Mean & $\begin{array}{c}\text { Verbal } \\
\text { Interpretation }\end{array}$ & Evaluation \\
\hline 1. Organizational Structure & 3.96 & $\begin{array}{c}\text { Agreed to } \\
\text { Great Extent }\end{array}$ & Very Satisfactory \\
\hline 2. Employer-Employee Relationship & 3.26 & $\begin{array}{c}\text { Agreed to } \\
\text { Some Extent }\end{array}$ & Satisfactory \\
\hline 3. Employee's Growth and Development & 3.50 & $\begin{array}{c}\text { Agreed to } \\
\text { Great Extent }\end{array}$ & Very Satisfactory \\
\hline Weighted Mean & 3.57 & $\begin{array}{c}\text { Agreed to } \\
\text { Great Extent }\end{array}$ & Very Satisfactory \\
\hline
\end{tabular}

to some extent" and evaluated as "satisfactory".

Overall, the organizational condition of the private schools and colleges got a mean of 3.57 with a verbal interpretation of "agreed to great extent" and evaluated as "very satisfactory". These results imply that the organization focuses on their goals and objectives and the growth and development of its employees.

\section{Conclusion}

Based on the gathered data and analysis of the results, the researchers concluded that the private schools and colleges of Nueva Ecija have demonstrated to be very satisfactory in their organizational condition. This was highlighted in the aspects of organizational structure and employee's growth and development. 
This focuses on the commitment of all the members in achieving goals and objectives of their organizations, and at the same time giving opportunities to all the members to become productive according to distributed roles, and responsibilities, acknowledging one's accomplishments, and group cohesiveness.

\section{Conflicts of Interest}

The authors declare no conflicts of interest regarding the publication of this paper.

\section{References}

[1] Bakker, A.B. and Schaufeli, W.B. (2008) Positive Organizational Behavior: Engaged Employees in Flourishing Organizations. Journal of Organizational Behavior: The International Journal of Industrial, Occupational and Organizational Psychology and Behavior, 29, 147-154. https://doi.org/10.1002/job.515

[2] Shoaf, C., Genaidy, A., Karwowski, W. and Huang, S.H. (2004) Improving Performance and Quality of Working Life: A Model for Organizational Health Assessment in Emerging Enterprises. Human Factors and Ergonomics in Manufacturing \& Service Industries, 14, 81-95. https://doi.org/10.1002/hfm.10053

[3] Orvik, A. and Axelsson, R. (2012) Organizational Health in Health Organizations: towards a Conceptualization. Scandinavian Journal of Caring Sciences, 26, 796-802. https://doi.org/10.1111/j.1471-6712.2012.00996.x

[4] Omoyemiju, M.A. and Adediwura, A.A. (2011) A Study of Teachers' Perception of Schools' Organizational Health in Osun State. World Journal of Education, 1, 165-170. https://doi.org/10.5430/wje.v1n1p165

[5] Grawitch, M.J., Gottschalk, M. and Munz, D.C. (2006) The Path to a Healthy Workplace: A Critical Review Linking Healthy Workplace Practices, Employee Well-Being, and Organizational Improvements. Consulting Psychology Journal: Practice and Research, 58, 129. https://doi.org/10.1037/1065-9293.58.3.129

[6] Yüceler, A., Doğanalp, B. and Kaya, Ş.D. (2013) The Relation between Organizational Health and Organizational Commitment. Mediterranean Journal of Social Sciences, 4, 781. https://doi.org/10.5901/mjss.2013.v4n10p781

[7] Farahani, M.F., Mirzamohamadi, M.H., Afsouran, N.R. and Mohammadi, S. (2014) The Study of the Relationship of Organizational Health of the Schools and That of the Student's Academic Achievement (A Case Study of High Schools of Kohkilouie and Boierahmad Province, Iran 2011). Procedia-Social and Behavioral Sciences, 109, 628-633. https://doi.org/10.1016/j.sbspro.2013.12.518

[8] Mehta, T.G., Atkins, M.S. and Frazier, S.L. (2013) The Organizational Health of Urban Elementary Schools: School Health and Teacher Functioning. School Mental Health, 5, 144-154. https://doi.org/10.1007/s12310-012-9099-4

[9] Williams, C. (2007) Research Methods. Journal of Business \& Economics Research $(J B E R), 5,65-72$.

[10] Salaria, N. (2012) Meaning of the Term Descriptive Survey Research Method. International Journal of Transformations in Business Management, 1, 1-7. 